\title{
Women in the Qur'an, Traditions and Interpretation
}

\author{
By Barbara Freyer Stowasser. Oxford, UK: Oxford Univer- \\ sity Press, 1994, $206 \mathrm{pp}$.
}

It takes a book like Barbara Freyer Stowasser's Women in the Qur'an, Traditions and Interpretation to help extricate the complex images of Muslim women from the gross overgeneralization characteristic of popular western media. Truly understanding that complexity requires a look at all of the components that make up the Islamic worldview, from its primary sources ideologically to its cultural history as it has affected the lives of Muslims. Such a look has been offered in Stowasser's book.

I was very excited by the cross-referential methodology proposed by the author in her introduction and her actual use of it throughout the text. She moves among Qur'anic passages, earlier tafäsïr, hadith traditions, as well as among contenders in modern Islamic discourse: modernists, traditionalists, and fundamentalists (pp. 5-7). As a result, the reader views different responses to ideas about specific women from the Qur'anic text while knowing precisely the source of certain ideas.

This is not the usual diatribe that confuses indiscriminately fact with mythology, intellectual tradition with popular culture, and results in misinforming the already ill-informed reader. Moreover, Stowasser avoids the other popular extreme: diminishing everything to a single factor, such as gross misogyny, for example. Although she distinguishes between the various strains that make up a complex picture, she does not merely regurgitate the historical legacy but rather offers critical analysis and demonstrates her capability in deciphering the various components in the internal Islamic debates as well.

Perhaps the complexity of the cross-referential methodology limits the breadth of the subject matter. We can understand how complex notions of the place of Muslim women in society have resulted from these various references, even though we get no hint at what that place is from this work. The characters analyzed are limited to the specific female characters given individual attention in the Qur'anic text and to the wives of the Prophet. These models of virtue and struggle, failure and frustration, can and have 
provided markers for the goals and aspirations of Muslim women in social contexts.

How they are markers was not the goal of this particular work, a fact that indicates its extra-Islamic methodological framework. Knowledge in Islam is that which must be used. To merely discuss these characters without making direct reference to how they might be and have been used in the context of Muslim society places this work into the category of theory. This can be seen as a positive asset, despite her statement that "women's issues have consistently played a major role" in the current moral debates where women "symbolize main aspects of the Islamic struggle for the maintenance of indigenous values and 'cultural authenticity"' (p. 5).

Thus, the first part of this book presents specific female characters believed to be actual historical figures who lived before the advent of Islam: Eve (the first woman); the wives of Noah, Lot, and Abraham; Zulaykhā; the sisters and natural and adopted mothers of Moses; Bilqīs; and Mary. In her treatment of these women, we are not given any information about their relationship to women in real Islamic social contexts. Instead, we are presented with an understanding of paradigmatic shifts on questions of doctrine and ethics within a context of some internal consistency.

In the second part, the focus is on the significant women in the Prophet's life during the budding Islamic community in Madinah. Her conclusion is that "Qur'anic legislation on the Prophet's domestic affairs progresses ... in the direction of increasing restraint not increasing 'liberation," " (p. 102), which does not include a clear definition of either liberation or restraint. Neither does it supply the indicative "chronological" evidence that such a statement might warrant. It is implied from the text that "women's secluded space, concealing clothing and unfitness for public activity" is the author's equivalent of "restraint" (p. 99). Thus issues like hijäb are covered.

At first, the discussion of hijäb follows the pattern and method established throughout the work in order to show the variety of responses to a single phenomenon. However, as the single most em-phasized item of discourse outside the consideration of particular women as mentioned in the Qur'an or who are significant in early Islamic history, the purpose of this discussion runs at cross-purposes with the focus of the remainder of the book. It is rightfully pointed out, via Qāsim Amin's understanding, that the hijäb was a cultural symbol of "institutionalized restriction on women that consisted of sexual segregation, domestic seclusion ..." (p. 127), with the modern equivalent, due to socioeconomic necessity and expanded education for women, of the "garment" worn by many "urban middle and lower middle class." Even after her lengthy discussion, however, it remains a complex and much misunderstood issue. 
Of the nearly two hundred pages, the notes cover sixty pages and are by far the "best" part of the book, especially for the non-Arabic reader. Stowasser's work is extremely well documented, and I would recommend it to specialists and students of Islamic thought and the issue of women.

Amina Wadud-Muhsin Women's Studies Department Virginia Commonwealth University

Richmond, Virginia 